\title{
REFLECTIVE READING JOURNAL IN TEACHING WRITING
}

\author{
Yanuarti Apsari \\ Department of English Education, Faculty of Language Education, IKIP Siliwangi, Indonesia \\ E-mail: yanuar.apsari1@gmail.com
}

APA Citation: Apsari, Y. (2018). Reflective reading journal in teaching writing. Indonesian EFL Journal, 4(2), 39-47. doi: 10.25134/ieflj.v4i2.1374.

\begin{abstract}
A number of studies suggested that journal writing is a supportive tool that encourages learners' reflective activity and that reflective thinking skills can be taught and learned. Accordingly, this study investigated the implementation of reflective reading journal in teaching writing as well as the benefits that the students obtained after writing reflective reading journal. This study employed a case study research design which used three data collection including observation, interview and students' texts. The results of the study revealed that reflective reading journal can be used effectively to improve students' writing skill through several ways. First, the students were required to produce clearly defined paragraphs which include two sections. The first section included referencing data, such as author and title, and a paraphrase of the reading. The second section contained a response to a specific aspect of the reading. Second, the participants of the research were involved in decision making of topics for reading. Third, they wrote reflective reading journal weekly. Fourth, teacher gave feedback to students' journal entries. In addition, the study also showed that there were some benefits, namely development of ideas, improvement of textual coherence, and Improvement of textual cohesion.
\end{abstract}

Keywords: reflective reading journal; writing; benefit; EFL; ELT.

\section{INTRODUCTION}

Writing is one of the important skills in teaching English. Harmer (2004, p. 31) states that writing has always formed part of the syllabus in the teaching English. As one of the four language skills, writing has always occupied place in most English language course. One of the reasons is that more and more people need to learn to write in English for occupational or academic purposes, especially for English department students, they need to learn writing and prepare themselves for the final academic assignment. Therefore, in terms of student's needs, writing ability is necessary.

According to Gebhard (1996), writing involves several components which have to be considered including word choice, use of appropriate grammar, syntax, mechanics, and organization of ideas into coherent and cohesive form. Accordingly, in producing writing students need to focus on how to generate ideas, how to organize them coherently, how to use discourse markers, and rhetorical conventions to put them cohesively into a written text, how to revise text for clearer meaning, how to edit text for appropriate grammar, and how to produce a final product (Brown, 2001). For that reason, writing is difficult to be acquired by students (Alwasilah, 2001).

Referring to the problem above, Hamp and Heasley (2006, p.5) suggested that the most obvious way you can help yourself become a good writer is by writing. Additionally, Zamel (cited in Nunan, 1991, p. 88) believes that writing skill can develop rapidly when students' concern and interests are acknowledged and they are given numerous opportunities to write. Thus, journal writing can be used as teaching and learning tool to develop students' writing skill (Harmer, 2001, p. $339 \&$ 2004, p. 127, Alwasilah, 2005, p. 105).

Many studies have been done to investigate the effectiveness of journal writing in language teaching to increase students' 
academic achievement. A research by Campbell (1998) on journal writing proved that journal writing can help the second language learners develop their oral and written skill. In addition, another study conducted by Chung (2001) revealed that journal writing helped to improve students' writing fluency in Korean, and created a positive attitude toward writing in Korean. Furthermore, Gallagher's study (1997) indicated that journal writing practice developed cohesion and text organization among the Japanese students studying English as a foreign language.

Reflective reading journal is a form of journal writing. Zamel (1992) states that reflective reading journal is the place where students' reactions to text are first recorded and reflected upon; where students' progress association, questions, and thought are written; and with which students make immediate connections between reading and writing.

Zanichkowsky (2004) suggests that in writing reflective reading journal, students are required to produce clearly defined paragraphs which include two sections. The first section included referencing data, such as author and title, and a paraphrase of the reading. The second sections contained a response to a specific aspect of the reading, rather than a general reaction to the reading as a whole.

Producing written response to text requires the student to analyze, from a number of different perspectives, the issues, themes, or concepts presented in that text. In composing a response, the student must think and rethink the text, focusing attention on the global elements of text, that is, on its overall meaning. Attending to the global elements of a text means that the student comes to understand its meaning by drawing connections to personal experience, knowledge, and other texts read. Accordingly, journal writing helps to train students to express their ideas (Lazarus, 1999).

Relating to the response to the reading text,the students are also encouraged to reflect on the learning event and exercise their judgement about the content and the process of learning that enable them to think critically (Norris and Ennis, 1989, p. 35). This means that having students compose a response also teaches them critical thinking skills, such as analysis, interpretation, inference, and synthesis of knowledge. Each of these has been identified as a major component of the process of meaning construction (Spires, Huntley-Johnston, and Huff-man, 1993).

Moreover, Cooper \& Kiger (2003) propose that for the effective implementation of reflective reading journal, the teacher should take the several stages into consideration. They are: 1) the teacher should explain the idea of journal writing to students; 2) the teacher writes a journal entry in the classroom in order to show students how this process is done; 3)With students, the teacher sets how frequently they should write in their journals and how often they should turn in their journals so that he or she can read andcomment on them; 4) students should be free to write on any topic that interests them; 5) during the initial stages of journal writing, teachers should set some group processing sessions in order to evaluate how the process is going and discuss the strengths and weaknesses of journal writing.

Based on the description above, it can be implied that in the procedure in writing reflective reading journal is in line with the suggestion of Harmer (2004) that it is useful to provide the students opportunity to express their feelings and opinion freely.

Considering the importance of journal in teaching writing, this study aims to investigate the implementation of Reflective Reading Journal in teaching writing as well as the benefits that the students obtained after writing Reflective Reading Journal.

\section{METHOD}

This study employed a qualitative approach which is considered appropriate to understand the process of reflective reading journal by which events and actions take place (Maxwell, 1996, p. 19). Moreover, this study can also be considered as a case study since it was conducted in a small scale, a single case, focus 
on one particular instance of educational practice that is teaching reading with the researcher acted as the teacher (Stake, 1995 cited in Emilia, 2005).

The study was conducted in English Education Study Program at STKIP Siliwangi Bandung, where the researcher is one of lecturers. The participants of this studywere second semester students in English department who are taking the subject of writing for general purposes.

In gaining the data, this study employed various techniques such as classroom observation, interview and students' texts. In this study, interview was used to gain specific information or very useful data about students' feeling or opinion which is notaccessible through observation (Merriam, 1998). Finally, students' reflective reading journal during the study were collected and analyzed to gain information regarding the development of their writing skills after writing reflective reading journals.

The students' journals were analyzed by focusing on three aspects of writing such as development ideas, textual coherence, and textual cohesion (Gebhard, 1996). In analyzing the data, the researcher integrated and related the findings to the background of the study, mainly to the research questions, theories, and the methodology for classifying the data into manageable units as suggested by Emilia (2008, p. 201).

\section{RESULTS AND DISCUSSION}

Relating to the research questions, the data from each source is presented under two themes: the implementation of reflective reading journal and the benefits that the students obtained from writing reflective reading journal.

\section{The implementation of reflective reading journal}

The teaching program consists of a series of activities: 1) one session of a preliminary phase; 2) one session of explicit teaching of reflective reading journal and 3) ten sessions of practicing writing reflective reading journal.

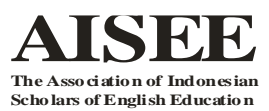

1) Preliminary phase of the teaching program The activities in the preliminary phase comprised the introduction to reflective reading journal and negotiating the topics for the reading texts. Each activity will be discussed below.

In the first meeting, the lecturer introduced the students to the program. It was conducted mainly for providing overall information and explicit direction regarding the course, and for giving explanation of the purpose of classroom activities.

The information covered the length of the course that would take 12 meetings at least 90 minutes for each session. Other requirements necessary for the study such as taking part in interview, filling in questionnaires and writing Reflective Reading Journal weekly were also clarified. As recommended by Peyton \& Staton (1991) that the journal is written at least once a week.

Furthermore, in this program, ten topics for the teaching program were offered to the students, including Will net replace thinking?, Till death do us part, New Discoveries in Psychology, Modern trend in management, Staying healthy, The Hawaian island, Shopping malls in the United Stated, How disease spread?, Electronic mail, and Elephant.These topics were offered because they represents several genres such as description, article, short story, argumentative, report and news item.

The respondents under this research were involved in decision making of topics for reading. This is inline with Gebhard's (1996) statement that students are much more likely to read with enthusiasm if they have made the decision about what they read.

The teaching program conducted in this study was adopted from the work of Cooper \& Kiger (2003). It was set out for twelve sessions starting from February to May 2016 and the duration for each meeting was 90 minutes.The teaching phase of this program can be broken down into two sections comprising the explicit teaching of reflective reading journal writing and practicing of 
reflective reading journal writing and this will be elaborated further below.

2) The explicit teaching of Reflective Reading Journal writing

In the attempt to make the explicit teaching well-organized, the first notion to explain was its definition. This explanation was followed by explaining the components of reflective reading journal.

Reflective Reading Journals generally consist of frequent, short, formal writing assignments that document students' reading process (Chick, 2004). It consists of three sections, including: 1) a title and some form of referencing for the material,2) an outline of the material, and 3) a personal reaction or response to the content of the material.

The students were required to include a personal reaction or response to each article. It is a central component to the support for Reflective Reading Journal. In composing written response to text,the studentswere required to analyze from a number of different perspectives, the issues, themes, or concepts presented in that text. In other words, the students must think and rethink about the text, focusing attention on the global elements of text, that is, on its overall meaning. Attending to the global elements of a text means that the student comes to understand its meaning by drawing connections to personal experience, knowledge, and other texts read. This is in accordance with Enright et.al's (1998) statement that they must integrate and connect the information presented by the author with what they already know.

3) The practicing of Reflective Reading Journal writing

This section particularly describes the implementation of reflective reading journal. The concept of reflective reading journal adopted in this study was drawn from Chick (2004) and Zanichkowsky (2004). The students were required to produce clearly defined paragraphs which include two sections. The first section included referencing data, such as author and title, and a paraphrase of the reading. The second sections contained a response to a specific aspect of the reading, rather than a general reaction to the reading as a whole.

Regarding the activities of text modelling, the students were distributed some copied of text and showed them how to make a journal. By providing students with a model or example, they can better understand how to compose a piece of writing more effectively and appropriately (Seow, 2002).

Furthermore, the teacher carefully read what students have posted in their journals in order to provide appropriate responses. The teacher wrote a comment at the end of journal entries which showed that they have been read. For example, a teacher wrote, 'well done', 'I enjoyed reading your journal', which is supportive comment but not very informative.

In the final journal entries, it was found that most students' writing quality developed. This might due to the effect of the feedback that they received on their journal entries. The students were frequently asked to elaborate on ideas they addressed when the meaning was not clear. Thus, teachers' response to students' journal entries is important as can enhance students' motivation to write more and provides them with other points they can address (Peyton \& Reed, 1990, p. 3).

\section{The benefits of writing reflective reading journal}

Based on the data from interview and students' journal entries, there are a lot of benefits that the students obtained after writing reflective reading journal. It is in line with Alwasilah's (2005) statement that journal provides a variety of benefits that might be obtained by the students.

The benefits are related towriting skill development such as development of expressing ideas and opinion, improvement of textual cohesion and coherence. The discussion of which will be presented below.

1) Development of ideas

With regard to writing ability, all respondents said that reflective reading journal helps them develop their writing skill. As confessed by $\mathrm{R} \# 3$ that before practising to write reflective 
reading journal she cannot develop the ideas in writing. She also did not understand the gramatical rules. But, now she can understand how to compose a good writing. Her understanding in grammar is also developed. Then, she got a lot of vocabularies from the activity.It is relevant with the findings of Song (1997), Chung (2001), and Farrah (2012) that journal writing developed students' writing quality.

This finding also is supported by the data from document analysis. One of the main areas of improvement that can be found in the first entry compared to the final entry is development of ideas. In the first entry, it was found that most students produced short sentences in simple language to expose their feelings or to reflect on their understanding on the text they read. It can be seen in the following excerpt:

Will the net replace thinking? Net thinkers are said to generate work quickly and make connections easily. "They are more in control of fact than we were 40 years ago" says Bernard Cooperman, a professor at the University of Maryland. But they also value information from gathering over deliberation, breadth over depth. (R\#3)

In her entry entitled "Will the net replace thinking?", R\#3 she did not write the journal based on their understanding on the text they read, but they just made the text shorter. She just picked and copied one paragraph in the introduction.

Furthermore, in that introduction she did not develop the idea stated by Bernard Cooperman. That was an important point on which she could have elaborated giving her opinion about the good side of internet. Rather, she abruptly move to another point stating about plagiarism. She said, "The problem is no longer plagiarism of huge fownloaded block of text-software can detect that now, when the teacher enters a few lines of a paper."

This finding indicates that she did not read some resources such as textbooks and articles to collect information about the topics that

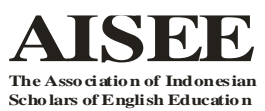

they were writing about. This is irrelevant with the recommendation of Enright et al. (1998) that the reader should integrate and connect the information presented by the author with what they already know.

However, in the final journal entries most students had more developed ideas.It can be seen from the body of their entries, they developed the main ideas that they presented in the introduction.It can be seen from the following exceprt, R\#3 tried to connectthe information from the text with the information from other sources:

The pollution in the ocean can spread disease. The pollutant such as chemicals from fertilizers and human waste can pollute the ocean and it can cause the increase of algae. According to Oxford dictionary, algae is a very small plants that are mainly found in water and it provides a home for cholera. According to www.wikipedia.com, cholera is an infection in the small intestine caused by bacterium Vibrio Cholera. It can grow in the dirty water and in uncooked food such as selfish. (R\#3)

This finding is relevant with the statement of Lazarus (1999) that journal writing helps to train students to express their ideas. This might due to the effect of the feedback that they received. The students were frequently asked to elaborate on ideas they addressed when the meaning was not clear. This is in accordance with Taylor's (1991) suggestion that in order to achieve considerable improvement students require feedback on their writing work.

\section{2) Improvement of textual coherence}

The analysis of students' journal entries revealed the differences between the first and the final entries in terms of textual coherence. In the first entry, most students did not present unified pieces of writing as they frequently made sudden shifts without preparing the reader for doing so, which negatively affected the overall meaning. An example of this can be found in R\#8 entry, represented low achiever. 
Daniel Davis says, we can find a whole pages of stuff (many kinds of subject matters). We need to know on the web fast. Computer technology has the biggest influence to the shape of young thinking skills. Net thinkers at school appear to value breadth over depth and other people's arguments over their own. (R\#8)

In this quote, R\#8 indicated the effect of computer technology on young thinking skills. But, she did not explain to the reader in what ways it can influence the thinking skills and why it is important for the net thinkers to value breadth over depth and other people's argument over their own. R\#8 abruptly shifted to another point proposing several research findings on the effect of internet. It can be seen below.

Kenneth Kotovsky, a psychology professor at Carnegia-Mellon University in Pittsburgh who has examined the study habits of young people says that the students first recourse for any kind of information is the web. It is absolutely automatic. According to Bernard Cooperman, a history professor at the University of the Maryland on the good side net thinkers are said to generate work quickly and make connection easily. They are more in control of fact than we were 40 years ago. The educators woried if the net thinkers at school appear to value breadth over depth and other people's arguments over their own. (R\#8)

In this quote, it is clear that one paragraph tells about several topics. The occurance of these shifts sounds confusing to the readers as it distract their understanding on the point that the writer is highlighting. This finding is in accordance with the view of Nunan (1999) that in term of skills, producing coherent, fluent and extended piece of writing is probably the most difficult thing to do in language learning.

In the final journal entries, students writing ability showed the improvement. Their writng tended to show logical sequence in presenting their arguments. Their writing appeared more coherent in that they started with a clear introduction and supported in with relevant information. This made their entries develop sequentially while their arguments sound more organized and convincing to the readers.

For example, R\#6 represented low achiever began her final journal entry on the topic, "How Disease Spread", with the following paragraph:

There are many things that cause diseases spread easily. Howeover, people are often unaware of it. But, this should be avoided to prevent the spread of disease. This article is about the cause that may lead to the spread of disease that need to be known by the reader. Thus, things that can trigger the spread of disease can be avoided. (R\#6)

In the subsequent paragraph, R\#6 discussed the people's movement as the cause of disease spread, with the following paragraph:

This is how the disease spreads from one
country to another. When people move from
one place to another, they bring the germs,
bacteria and viruses. They spread the virus
easily since infectious disease spread
through direct contact, food, insect or
airbone method. (R\#6)

In the third paragraph, R\#6 explained the solution of the problem stated above. She said, "for example, by injecting the sterilization of pilgrims who will travel to the holy land of Mecca. So they will not carry the virus when leaving and when returning from Mecca". Then, she explained another causes of the spread of disease and its solution. She concluded her entry by commenting the importance of cleanliness.

This finding is relevant with the statement of Dorn and Soffos (2005, p. 47) that writing helps students integrate different sources of information and organize their thought, thus, their thinking is more fluid, flexible and tangible.

\section{3) Improvement of textual cohesion}

The analysis of students' journal entries revealed the differences between the first and the final entries in terms of textual cohesion. In the following text, the special attention is used for cohesion devices. Analysis of 
students' first entries showed that their writing lacked cohesion devices. More specifically, students rarely used transition markers which resulted in making their writing less connected. As a result, their journals were difficult to understand. it can be seen from the following journal entry:

Internet has contributed so much to society, company/industry, and government. Internet presence has been supporting the effectiveness and efficiency of company operations, particularly its role as a means of communication, publication and the means to obtain information needed by a business entity and form a business entity or other organization. Role the internet is currently the most commonly used by people of relatively young age, students rely heavily on the internet to complete their task. (R\#9)

The above excerpt from R\#9 seemed to lack transition devices. She tended to start every sentence with the same noun phrase "the internet". It would be more cohesive if she instead replaced "the internet" with the subject pronoun "it". Similarly, using enumeration devices such as first, second, third, and finally makes text more cohesive and easier to understand.

In the final entry, students used more cohesion devices that made their writing more tied together and, in turn, coherent. An example of a cohesive excerpt from the final entries can be found in R\#3's entry where she used some cohesion devices such as for example, before, as a result, and therefore:

Let's begin with the explanation about the
spread of germ from person to person. Germ
can spread easily from person to person. For
example, if people move from one city or
country to another, they often bring a new
germ that may not have been present in the
region before. As a result, people who
already live there become ill more easily
and die more often because they don't have
an immunity to protect their body from the
spread of germ. Therefore, to solve the
problem we have to protect our bodies with
giving immunization. (R\#3)

Another example can be reviewed in $\mathrm{R} \# 9$ entry about the aging population in industrialized countries. R\#9used some cohesion devices such as now, in the past, but, and thus to connect his ideas together. She said:

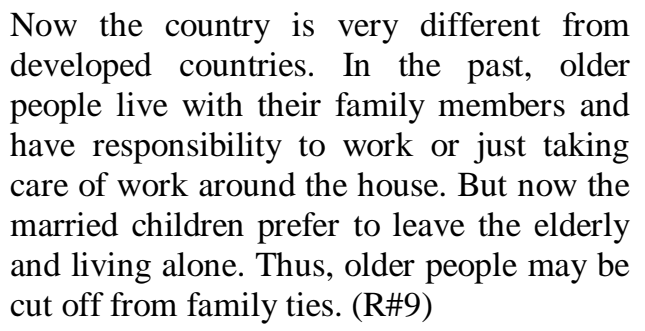
developed countries. In the past, older people live with their family members and have responsibility to work or just taking care of work around the house. But now the married children prefer to leave the elderly and living alone. Thus, older people may be cut off from family ties. (R\#9)

For practicality reason, the analysis was limited to transition markers such as "on the other hand, on the contrary, in fact, therefore, as a result, for example, for instance, in addition" and enumeration devices like "firstly and finally." The Results revealed that the nine students included in the analysis used a total of 19 transition markers in the first journal entries and 128 markers in the final entries. The average number of transition devices each student used in the first entry was 2.1 compared to an average of 14.2 in the final entry. This means that the number of the transition markers used in the final entries was almost seven times as much as the number of those used in the first entries.

The findings above were in accordance with the finding of Gallagher (1997) that journal writing practice developed cohesion and text organization among the Japanese students studying English as a foreign language.

\section{CONCLUSION}

This study investigates the implementation of reflective reading journal in teaching writing. The concept of reflective reading journal adopted in this study was drawn from Chick (2004) and Zanichkowsky (2004). In this study, the students were required to produce clearly defined paragraphs which include two sections. The first section included referencing data, such as author and title, and a paraphrase of the reading. The second sections contained a response to a specific aspect of the reading, 
rather than a general reaction to the reading as a whole.

Furthermore, this study revealed that there are a lot of benefits that the students obtained after writing reflective reading journal. The benefits are related to writing skill development such as development of expressing ideas and opinion, improvement of textual cohesion and coherence. This means that reflective reading journal writing develops the students' writing quality.

Based on the conclusions above, some recommendations are suggested to the teachersand other researchers.

Teachers need to provide the students opportunity to select the reading material in applying reflective reading journal. Students are much more likely to read with enthusiasm if they have made the decision about what they read (Gebhard, 1996). As a result, they can select the reading material that can meet students' need and that are interesting to them.

Furthermore, concerning the benefits that the students obtained from writing reflective reading journal, it is better for the students to get into the habit of writing regularly. In this case, they should be encouraged to write continuously on any topic of their choice.

Finally, as this research only concerns with the use of reflective reading journal at University level, it will be beneficial if there will be other research on the use of reflective reading journal for lower levels.

\section{REFERENCES}

Alwasilah, A. C. (2001). Language, culture, and education: A potrait of temporary Indonesia. Bandung: Andira.

Alwasilah, A. C. (2005). Pokoknya menulis. Bandung: Kiblat Buku Utama.

Brown, H. D. (2001). Teaching by principles: An interactive approach to language teaching. White Plains, NY: Addison Wesley Longman.

Campbell, C. (1998). Teaching second-language writing: Interacting with text. Pacific Grove: Heinle \& Heinle.

Chick, N. (2004). Reading logs. Retrieved February, $28^{\text {th }}$ 2016 from: http://www.uwc.edu/uwc/depts/english/Teaching_ Tips/ChickRLogs.htm

Chung, H. Y. (2001). Reflective journal writing in the foreign language classroom (Korean II).
Unpublished MA Thesis, Faculty of Rosier School, University of Southern California.

Cooper, J. D., \& Kiger, N. D. (2003). Literacy: helping children construct meaning $\left(5^{\text {th }} e d\right)$. Boston: Houghton Mifflin.

Emilia, E. (2005). A critical genre based approach to teaching academic writing in a tertiary EFL context in Indonesia. Australia: The University of Melbourne.

Emilia, E. (2008). Menulis tesis dan disertasi. Bandung, Indonesia: Alfabeta.

Enright, M., Grabe, W., Mosenthal, P., Mulcahy-Ernt, P., \& Schedl, M. (1998). A TOEFL 2000 framework for testing reading comprehension: A working paper. Princeton, NJ: Educational Testing Service.

Gallagher, C. (1997). Journal writing in EFL: A systemic functional account. Language Research Bulletin, 12, 57-73.

Gebhard, J. G. (1996). Teaching English as a foreign or second language. Ann Arbor: The University of Michigan Press.

Hamp, L., \& Heasly, B. (2006). Study writing ( $2^{\text {nd }}$ ed.). Cambridge: Cambridge University Press.

Harmer, J. (2001). The practice of English language teaching. England: Longman.

Harmer, J. (2004). How to teach writing. UK: Pearson Education Limited.

Lazarus, K. (1999). Journal writing: A path to academic writing for basic writers. Journal for Teachers of at-risk College Writers (pp. 7-18). Portsmouth NH: Boyntory Cook Publisher, Inc.

Maxwell, J. A. (1996). Qualitative data analysis: A source book of new methods. London: Beverly Hills.

Merriam, S. B. (1998). Qualitative research and case study applications in education. California: Jossey- Bass, Inc.

Norris, S. P., \& Ennis, R. H. (1989). Evaluating critical thinking. Victoria: Midwest Publication.

Nunan, D. (1991). Language teaching methodology: A text book for teachers. London: Prentice Hall International (UK) Ltd.

Nunan, D. (1999). Second language teaching and learning. Boston: Heinle \& Heinle Publisher.

Peyton, J. K., \& Reed, L. (1990). Dialogue journal writing with nonnative speakers: A handbook for teachers. Alexandria: Teachers of English for Speakers of Other Languages, Inc.

Peyton, J. K., \& Staton, J. (1991). Writing our lives: reflection on dialogue journal writing with adults learning English. Englewood Cliffs, NJ: A Simon \& Schuster Company.

Seow, A. (2002). The writing process and process writing. In J. C. Richard, \& W. A. Renandya (Eds.), Methodology in language teaching: An anthology of current practice (pp. 315-320). Cambridge: Cambridge University Press. 
Spires, H. A., Lu H. J., \& Lois E. H. (1993). Developing a critical stance toward text through reading, writing, and speaking. Journal of Reading, 37, 114-22.

Zamel, V. (1992). Writing one's way into reading. TESOL Quarterly, 26(3), 463-485.

Zanichkowsky, E. (2004). Reading logs: Instructions and grading guidelines. Retrieved from http://www.uwc.edu/uwc/depts/english/Teaching_ Tips 